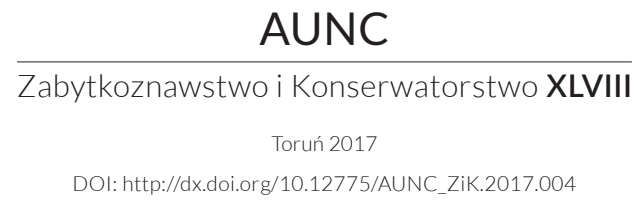

\title{
Patrocinium publicum Juliusa Schottländera
}

\author{
BOŻENA GRZEGORCZYK \\ Zakład Historii Sztuki Średniowiecznej i Nowożytnej, \\ Wydział Sztuk Pięknych, UMK w Toruniu \\ e-mail: b.grzeg@umk.pl
}

Keywords: 19th century, Wrocław, civic patronage, Julius Schottländer.

Słowa kluczowe: XIX wiek, Wrocław, patronat obywatelski, Julius Schottländer.

\begin{abstract}
Juliusa Schottländer's Parimonium publicum

Julius Schottländer (1835-1911), a figure often referred to by historians and art or architectural historians, is undoubtedly a figure to whom Wroclaw owes very much concerning the formation of a new kind of urban structure.

Not much can be said about Juliuses' childhood or adolescence. It is typiclal, that although his father Löbe was a wealthy man, 15 year old Julius already started to run his own business, in the beginning he traded corn, later provided supplies for the army and in the end he opened a banking firm, which soon jointly created the Silesian Company for Real Estate. Julius was also highly interested in affairs of the city, which he gave several charities, amongst with the South Park.

Taking in account the entire acceptance of the activities of the Jewish entrepreneur, it is surprising, that no researcher ever took up the assessment of his achievements. One could argue, that the main obstacle in assessing the achievements critically, lies in the absence of an adequate/suitable perspective, which would enable a proper look to his achievements and a judgement of his position in regard to the beneficiaries. It seems, that in this case the Roman term patrocinium publicum or civic patronage can be helpful.
\end{abstract}




\begin{abstract}
Abstrakt
Parimonium publicum Juliusa Schottländera

Julius Schottländer (1835-1911), postać często przywoływana przez historyków, historyków sztuki i architektury jest bez wątpienia postacią, której Wrocław zawdzięczał bardzo wiele w zakresie kształtowania nowego rodzaju struktur miejskich.

Nie wiele możemy powiedzieć o dzieciństwie i młodości Juliusa. Charakterystyczne, że choć jego ojciec Löbe należał do osób zamożnych, to Julius już w wieku 15 lat rozpoczął samodzielną działalność handlową, początkowo zajmował się handlem zbożem, potem zaopatrzeniem dla wojska, by wreszcie założyć firmę bankową, która współtworzyła niebawem Śląskie Towarzystwo Handli Nieruchomościami. Był Julius także żywo zainteresowany sprawami miasta, któremu nadal kilka fundacji dobroczynnych, w tym Park Południowy.

Znamienne, że przy całkowitej akceptacji działalności tego żydowskiego przedsiębiorcy, nikt z badaczy nie podjął się oceny jego dokonań. Można przyjąć, że główną przeszkodą, by poddać krytycznej ocenie jego działalność, tkwi w braku znalezienia adekwatnej/odpowiedniej perspektywy, która by umożliwiła właściwe spojrzenie na jego dokonania i osądzenie jego postawy względem obdarowanych. Wydaje się, że w tym przypadku bardzo pomocna może okazać się rzymska kategoria patrocinium publicum czyli patronatu obywatelskiego.
\end{abstract}

W opublikowanej przed kilku laty książce Pałace-instytucje dziewiętnastowiecznego Wrocławia - znak patronatu obywatelskiego starałam się naszkicować obraz Wrocławia jako miasta, które swój architektoniczny wizerunek w dużej mierze zawdzięczało działaniom mieszkańców. Przedmiotem rozważań był zatem obszar aktywności miejskiej wspólnoty. Przyjęłam wówczas, że skonsolidowane poczynania mieszkańców w pełni adekwatnie określa pojęcie „patronat obywatelski”, rozumiane jako wzajemna relacja między tymi mieszkańcami Wrocławia, którym wraz z wejściem w życie nowej ordynacji miejskiej - z 19 listopada 1808 roku - przysługiwało miano obywateli, a ich podopiecznymi ${ }^{1}$. W ordynacji bowiem społeczność miejską podzielono na dwie klasy: obywateli i tzw. podopiecznych, obie obligując do uczestnictwa w życiu gminy miejskiej. Członkiem klasy obywateli mógł być tylko posiadacz praw miejskich. Podobnie jak w okresie wcześniejszym zostawał nim właściciel działki (także kobieta) położonej w obrębie miejscowego okręgu policyjnego, zajmujący się określonym rodzajem działalności

1 Bożena Grzegorczyk, Pałace-instytucje dziewiętnastowiecznego Wrocławia - znak patronatu obywatelskiego (Toruń: Wydawnictwo Naukowe UMK, 2014), 44-46. 
gospodarczej. Każdy, kto szczycił się mianem obywatela, był zobowiązany do złożenia przysięgi przed magistratem. Pozostali mieszkańcy stanowili klasę podopiecznych. Cały system został tak pomyślany, by przywilej rządzenia miastem przysługiwał najwyżej uposażonym. Wydaje się wszak, że jego efektem było także z jednej strony zainteresowanie i zrozumienie obywateli dla nowych potrzeb miasta, z czym wiązał się ich aktywny udział w jego obszarze gospodarczym, z drugiej zaś strony - pojawienie się przesłanek dla konsolidacji społeczności miejskiej. Przyjęty tu sposób postrzegania patronatu obywatelskiego nie w pełni odpowiada modelowi patrocinium publicum w jego prymarnym znaczeniu, które ukształtowało się w okresie Cesarstwa Rzymskiego i dotyczyło prawnej umowy określającej relacje między patronem a jego podopiecznym. Stosując termin „patronat” chciałam uniknąć przede wszystkim kontrowersji wynikających z funkcjonowania szeregu pojęć o pozornie zbliżonym ładunku znaczeniowym (np. mecenat, protektorat, fundacja), które - rozumiane w sposób nazbyt ogólny - często bywają traktowane jako synonimy. Zatem „mecenat” oznacza świadome działania wykształconych znawców sztuki, mające na celu wsparcie żyjących, utalentowanych artystów i ich twórczości, natomiast „patronat” - opiekę i pomoc potrzebującym, którą niekoniecznie sprawuje wykształcony i obyty w świecie znawca. Bez wątpienia efektem tak określonego patronatu obywateli Wrocławia były gmachy i założenia o charakterze wysoce reprezentacyjnym (Giełda kupiecka zwana Starą, Nowa Giełda, Giełda zbożowa, Teatr Miejski, Ogród Zoologiczny, Muzeum Śląskie, Zakłady Kąpielowe), które powstały z myślą zarówno o mieszkańcach, jak i osobach przebywających w mieście przejazdem, w związku z interesami bądź z innych powodów². Rosnące potrzeby cywilizacyjne oraz kulturowe i światopoglądowe mieszkańców w tym czasie wymagały nowych przedsięwzięć publicznych. Należy przyjąć - choćby z tego względu, że rząd w Berlinie wyraźnie powstrzymywał się od jakichkolwiek inwestycji cywilnych we Wrocławiu - że wspomniane obiekty wzniesione wspólnym wysiłkiem mieszkańców stanowiły nie tylko ważne akcenty w pejzażu urbanistycznym, ale również znaki komunikujące o gospodarczym statusie miasta i świadectwo zamożności wrocławian, preferujących określone wartości.

2 Wrocław był wówczas centrum prawno-administracyjnym prowincji śląskiej, załatwiano tutaj wszelkie sprawy handlowe, administracyjne, sądownicze, bankowo-kredytowe. Był też stacją przesiadkową dla udających się do kurortów w Karkonoszach. 
Tak sformułowany problem zadecydował o tym, że stosunkowo niewiele miejsca w wymienionej pracy poświęciłam poszczególnym obywatelom, którzy w tym czasie angażowali się, w pełni świadomie, w przeobrażenia struktury miasta. Nie ulega wątpliwości (co wielokrotnie zaznaczyłam), że szereg podjętych - i co więcej: zakończonych sukcesem - przedsięwzięć był efektem złożonych działań zainicjowanych przez wrocławian, którym w szczególny sposób zależało na pozytywnym wizerunku miasta i jego wszechstronnym rozwoju. Ludzie ci pragnęli, by przybysze postrzegali stolicę śląskiej prowincji jako miasto wyjątkowe: doskonale prosperujące pod każdym względem, z korzystną koniunkturą w każdym obszarze, w którym mieszkańcom żyje się dobrze.

Jednym z obywateli, którym Wrocław zawdzięczał bardzo wiele w zakresie kształtowania nowego typu struktur miejskich, był Juliusz Schottländer - postać często przywoływana w pracach zarówno historyków ${ }^{3}$, jak i historyków sztuki ${ }^{4}$, z zwłaszcza historyków architektury ${ }^{5}$. Znamienne, że przy całkowitej akceptacji działalności tego żydowskiego przedsiębiorcy, żaden badacz nie podjął się jej oceny. Leszek Ziątkowski ${ }^{6}$ posłużył się osobą Schottländera, by wykazać, jak przebiegała kariera, a zarazem awans społeczny Żydów w drugiej połowie XIX stulecia, natomiast pozostali autorzy ograniczyli się w zasadzie do zaprezentowania jego pojedynczych dokonań, by w sposób bardziej lub mniej oględny ukazać go jako darczyńcę Wrocławia. Można sądzić, że główna przeszkoda w poddaniu działań przedsiębiorcy krytycznej ocenie tkwi w braku odpowiedniej perspektywy, umożliwiającej ich właściwy ogląd i osądzenie postawy Schottländera wobec obdarowanych.

Wydaje się, że bardzo pomocna może się tu okazać rzymska kategoria patrocinium publicum, czyli patronatu obywatelskiego. Rozważania patronatu zainaugurował przed ponad stuleciem Mathias Gelze rozprawą habilitacyjną

\footnotetext{
Aron Heppner, Jüdische Persönalichkeiten in und das Breslau (Breslau: Th. Schatzky, 1931), 17; Maciej Łagiewski, Wrocławscy Żydzi 1850-1944 (Wrocław: Muzeum Historyczne, 1994), 57-59; Leszek Ziątkowski, „Julius Schottländer (1835-1911). Przykład finansowej i społecznej kariery Żydów wrocławskich”, Sobótka 54 (1999): 365-373.

4 Iwona Bińkowska, Natura i miasto. Publiczna zieleń miejska we Wrocławiu od schyłku XVIII do początków XX wieku (Wrocław: Muzeum Architektury, 2006), 169-170.

5 Agnieszka Tomaszewicz, „Osiedle Borek - historia i architektura (1871-1914)”, w Przedmieście Świdnickie we Wrocławiu, red. Halina Okólska (Wrocław: Wydawnictwo GAJT, 2012), 98-110.

6 Ziątkowski, „Julius Schottländer”, 368-373.
} 
Nobilität $t^{7}$, przygotowaną i obronioną w 1912 roku na uniwersytecie we Freiburgu (opartą) zresztą na dziewiętnastowiecznych publikacjach autorstwa Theodora Mommsena ${ }^{8}$ i Joachima Marquarta ${ }^{9}$ ). Do problematyki tej powrócono w latach pięćdziesiątych XX wieku w licznych monografiach (między innymi Ernsta Badiana ${ }^{10}$ oraz Louisa Harmanda ${ }^{11}$ ) i w zasadzie te badania trwają do dziś, o czym świadczy wydana nie tak dawno praca Johna Nicol$\mathrm{sa}^{12}$. W ostatnich latach ukazało się wiele opracowań, w których zjawisko patronatu publicznego jest rozpatrywane w szerszym kontekście - nie tylko historii Cesarstwa Rzymskiego, ale i dziejów nowoczesnej Europy; zwraca się też uwagę na pewnego rodzaju podobieństwa w relacjach społecznych, jakie wystąpiły na przełomie XIX i XX wieku. Zagadnienie patronatu w nowym kontekście analizowali Ingo Kolboom w artykule z 1984 r. (w odniesieniu do Francji) ${ }^{13}$, Luigi Musella w tekście z 1985 r. (dotyczącym Włoch) ${ }^{14}$, Javier Moreno-Luzón w artykule z 2007 r. (pisząc o Hiszpanii) ${ }^{15}$ oraz autorzy prac zbiorowych, na przykład Jean-Louis Briquet i Frédéric Sawicki w publikacji z 1998 r. ${ }^{16}$, Ronald G. Asch, Brigit Emich i Jens Ivo Engels w książce z 2011 r. ${ }^{17}$ oraz Frédéric Monier, Olivier Dard i Jens Ivo Engels w zbiorze rozpraw poświęconych problemowi korupcji obserwowanej we współczesnym świe$\mathrm{cie}^{18}$. Wszyscy wymienieni autorzy sygnalizują, że zjawisko klientelizmu, tak charakterystyczne dla patrocinium publicum, jest znane zarówno w Europie

7 Mathias Gelzer, Nobilität der römischen Republik(Stuttgart: Teubner Studentbücher Geschichte, 1983).

8 Theodor Mommsen, „Das römische Gastrecht und die römische Clientele”, Römische Forschungen 1 (1864): 319-390.

9 Joachim Marquardt, Das Privatlebender Römer (Leipzig: Hirzel, 1886).

10 Ernst Badian, Foregin Clientelae, 264-70 B.C. (Oxford: Oxford University Press, 1958).

11 Louis Harmand, Le patronat sur les collectivité publique des orgines au bas empire (Paris: Presses Universitaires de France, 1957).

12 John Nicols, Civic Patronage in the Roman Empire (Leiden: Koninklije Brill NV, 2014).

13 Ingo Kolboom, „Patron et patronat. Histoire sociale du concept de patronat en France au 19e et 20e siècle”, Mots 9 (1984): 89-112.

14 Luigi Musella, "Clientélisme politique et raport entre pouvoir local et système parlamentaire dans la sud d'Italie continentale à la fin de XIX siècle”, Mélange d'école français de Rome 197 (1985): 431-440.

15 Javier Moreno-Luzón, „Political Clientelism, Elites and Caciquisno in Restoration Spain (1875-1923)", European History Quarterly 3, no. 37 (2007): 417.

16 Jean-Louis Briquet i Frédéric Sawicki, Clientélisme politique dans la sociétés contemporaines (Paris: Presses Universitaires de France, 1998).

17 Ronald G. Asch, Brigit Emich i Jens-Ivo Engels, Legitimation. Konsumption. Politische Patronage in Früher Neuzeit und Moderne (Frankfurt am Main: P. Lang, 2011).

18 Frédéric Monier, Olivier Dard i Jens Ivo Engels, Patronage et coruptions politiques dans l'Europe contemporaine (Paris: Armand Colin, 2014). 
(Francja, Włochy, Hiszpania), jak i w krajach afrykańskich, Brazylii, Japonii. Co symptomatyczne, klientelizm w XIX i XX wieku jest przez nich oceniany zdecydowanie negatywnie, jako forma korupcji, która ma podłoże ekonomiczne. Owe podejście współczesnych autorów, reprezentujących różne środowiska badawcze, oczywiście nie zaskakuje. Jednak zastrzeżenia wobec patronatu - nawet jego pozytywnych aspektów - zgłaszają nie tylko badacze zajmujący się współczesnością; sceptycznie podchodzi do rzymskiego patronatu na przykład Fergus Millar, który swoje rozważania zamyka konkluzją: „rzeczywiste znaczenie systemu patronackiego nie jest w pełni wyraźne”19.

Elementy patronatu można spotkać w każdej niemal epoce historycznej, zarówno w cywilizacjach starożytnych, jak i współcześnie, lecz wśród badaczy panują duże rozbieżności w kwestii terminologii. O trudnościach w tym zakresie świadczą choćby pojęcia znane z Rzymskiego Cesarstwa: patrocinium, patronatus, fides i clientela opisują różne aspekty tego samego zjawiska, natomiast beneficia i officia mają zasadniczo odmienne znaczenie. Patronat zazwyczaj definiuje się jako obopólną wymianę między ludźmi (patronem a klientem), którzy mają odmienny status i różne środki finansowe, przy czym wymiana dotyczy zarówno towaru, jak i usług. Jest to więc swoistego rodzaju moralny obowiązek dla obu stron; ze strony beneficjenta oznacza on wzajemność w stosunku do patrona, a ze strony patrona poparcie beneficjenta. O ile w Cesarstwie Rzymskim zawarty kontrakt opisujący wzajemne relacje był potwierdzany przez Tabulae patronatus, o tyle w czasach nowszych nie zawsze obowiązywała zasada prawnej regulacji między udziałowcami. W rzymskiej ideologii wymiana dóbr i usług opierała się na dobrej woli oraz teoretycznej kontynuacji i nie mogła być dalej rozwijana, jeżeli jedna bądź druga strona kontraktu była nieusatysfakcjonowana ${ }^{20}$.

Patroni starali się zwłaszcza zabezpieczyć potrzeby mieszkańców, wznosząc ze swoich funduszy założenia architektonicznee stanowiące cywilizacyjne udogodnienia dla życia wspólnoty, głównie sytuowane w centrum miast. Jeśli patronem była jednostka, a klientelą wspólnota miejska, wówczas łączyła ich też relacja określana przez prawo jako patrocinium publicum. Patroni wznosili zarówno budowle publiczne (mury, bramy miejskie, łaźnie itp.), jak i sakralne, ponadto brali udział w negocjacjach dotyczących wewnętrznych sporów, bronili wspólnoty, starali się podnosić jej status wobec cesarza. W za-

19 Fergus Millar, The Emperor and the Roman World, 31 B.C. - A.D. 337 (Ithaca: Cornell University Press, 1977), 315.

20 Nicols, Civic Patronage, 4-10. 
mian klienci (czyli wspólnota) troszczyli się o pomniki stawiane patronom jako wyraz wdzięczności i opiewali przy różnych okazjach szczodrość darczyńców. Z kolei w trakcie politycznych zmagań, na przykład w czasach późnej Republiki Rzymskiej, wielkie rody i znakomite osobistości - choćby Cezar, Pompejusz, Oktawian - wykorzystywały zasoby swojej klienteli, rywalizując o autorytet, władzę, prestiż. W Rzymie pod patronatem Augusta zbudowano dom senatu, świątynie i portyki, odrestaurowany został Kapitol oraz Teatr Pompejusza, wznoszono akwedukty, bazyliki, liczne budynki na Forum Romanum, powstało Forum Augusta. Niewątpliwie te działania przyczyniły się do rozwoju miasta, a przy tym podniosły jego splendor.

Mając w pamięci znaczenie terminu patrocinium publicum, wróćmy do osoby Juliusa Schottländera. Przyszedł na świat w Ziębicach, niewielkim śląskim miasteczku, w rodzinie żydowskiego kupca Löbla i jego żony Henrietty, 16 marca 1835 r. - w niepewnych czasach między kongresem wiedeńskim (1815) a Wiosną Ludów (1848). Dla całego społeczeństwa pruskiego, w tym i dla Żydów, był to okres nadziei i dynamicznego rozwoju. Zasiane przed laty idee Mendelssohna sprawiły, że zmieniła się mentalność Żydów. Wydaje się, że rodzina Schottländerów, podobnie jak i większość świeckiego środowiska żydowskiego, uwierzyła w etos spokojnego, mieszczańskiego życia, który dla społeczności żydowskiej oznaczał też kres wielowiekowej tułaczki w diasporze. Można przyjąć, że od najmłodszych lat Julius wychowywał się w atmosferze wiary w możliwość współpracy z chrześcijańską większością bez konieczności utraty własnej tożsamości i związków z własną religią i kulturą. Świadczy o tym choćby decyzja rodziców o nadaniu sześciorgu dzieciom imion niewywodzących się z tradycji żydowskiej - dziewczynki otrzymały imiona Auguste, Louise i Paula, natomiast chłopcy Bruno, Salo i Julius. Nie ulega wątpliwości, że rodzice świadomie wyrazili w ten sposób swoje proasymilacyjne i prokulturowe nastawienie.

Niewiele można powiedzieć o dzieciństwie i wczesnej młodości Juliusa. Wiadomo, że jego ojciec Löbel, twórca finansowej zasobności rodziny, należał do osób majętnych - był właścicielem „Cementfabrik-Aktien-Gesellschaft für Portland" w Opolu oraz rozlewni wód mineralnych w Karlovych Varach, ponadto w ciągu swojego życia zgromadził liczne posiadłości ziemskie (Bartoszowice, Pustkowa Wilczkowska, Prędocin Zwanowice, Sulistrowice k. Sobótki). Mimo zamożności ojca Julius bardzo wcześnie, w wieku 15 lat rozpoczął samodzielną działalność handlową, zajmując się sprzedażą zboża i wełny. Wczesna aktywność zawodowa Schottländera juniora wskazuje, że jego wy- 
kształcenie musiało być bardzo skromne. Można przypuszczać, że Schottländer senior przede wszystkim lokował pieniądze w grunty, natomiast od synów wymagał, by od najmłodszych lat wprawiali się w przedsiębiorczości, nabywając praktycznych umiejętności w zakresie handlu, i szybko się usamodzielnili. Dwudziestoczteroletni Julius wraz ze swoim kuzynem Louisem Pacullym prowadził już przedsiębiorstwo handlowe we Wrocławiu, choć nadal mieszkał w Ziębicach. Do Wrocławia ostatecznie przeniósł się na przełomie 1860/1861 roku i dalej zajmował się maklersko-hurtowym handlem zbożem, współpracując z kuzynem praktycznie do 1866 roku. W tym samym czasie wydzierżawił od miasta tzw. młyn środkowy. Inwestycja okazała się wyjątkowo trafnym przedsięwzięciem; zyski znacznie się podniosły po zainstalowaniu w zakładzie tzw. amerykańskiego młyna ciągłego i uruchomieniu olejarni i rafinerii oleju. W następnych latach Schottländer junior rozszerzył działalność o własną firmę bankową.

Wraz ze wzrostem kapitału rósł prestiż rodziny Schottländerów i samego Juliusa. Löbelowi i jego synowi w roku 1870 powierzono zaopatrzenie w żywność 6 Korpusu Armijnego, a Juliusowi również zaprowiantowanie całej 3 Armii. Nie ulega wątpliwości, że była to oferta wyjątkowo intratna pod względem finansowym. Kontrakt na samodzielne zaprowiantowanie zwycięskiej w wojnie francusko-pruskiej 3 Armii zapewnił żydowskiemu przedsiębiorcy stabilizację finansową, a ponadto umożliwił przesunięcie części kapitału do bardziej długofalowych i pewniejszych dziedzin, choć może nie tak zyskownych ${ }^{21}$.

Firma bankowa Juliusa nie do końca spełniła jego oczekiwania, na co miała wpływ narastająca konkurencja ze strony banków pruskich, które w kolejnych latach nasiliły ekspansję na tereny Śląska. Na Śląsku działały bowiem małe towarzystwa bankowe, najczęściej rodzinne, o niewielkim kapitale, tymczasem w położonych centralnie dzielnicach pruskiego państwa rosły potężne korporacje bankowe, z ogromnym potencjałem finansowym. W tej sytuacji Julius skupił swoją uwagę na handlu ziemią. W latach czterdziestych XIX wieku, wraz z doprowadzeniem do Wrocławia kolei, wzrosło zainteresowanie terenami budowlanymi, zwłaszcza położonymi na przedmieściach. Znaczne ożywienie można było zaobserwować nie tylko w budownictwie mieszkaniowym - już w pierwszej połowie stulecia postawiono obiekty fabryczne stanowiące zalążek przyszłej infrastruktury przemysłowej. Ponadto w mieście

21 Ziątkowski, „Julius Schottländer”, 370-371. 
dynamicznie rozwijał się handel detaliczny i hurtowy, powstawały liczne korporacje kupieckie, spółki akcyjne i instytucje kredytowe. Wzrosło zatem zapotrzebowanie na budynki przeznaczone dla instytucji i organizacji o charakterze ekonomicznym. Możliwość osiągnięcia sporych dochodów, jaką w tym okresie zapewniał handel gruntami, sprzyjała zakładaniu akcyjnych spółek budowlanych. Jedną z nich było Śląskie Towarzystwo Handlu Nieruchomościami (Schlesische Immobilen Actien Gesaellschaft), utworzone 31 października 1871 r. między innymi z inicjatywy Juliusa Schottländera. Oprócz niego do rady nadzorczej weszli przedstawiciele elity finansowej miasta: sędzia miejski David Friedländer, kupiec Carl Kärger oraz wrocławscy potentaci bankowi: August Schmieder, Sigmund Sachs i August Moser. Spółki te w zasadzie prowadziły zbliżoną działalność. Przede wszystkim starały się pozyskać tereny budowlane przy nowo wytyczanych ulicach, a następnie dzieliły je na działki, które sprzedawały z zyskiem mieszczańskiej klienteli. Spółki nie wyzbywały się jednak wszystkich gruntów - działki położone w najlepszych punktach miasta zazwyczaj zagospodarowywały we własnym zakresie, zabudowując je zespołami kamienic o niezwykle reprezentacyjnej architekturze. Eksplozji budowlanej lat siedemdziesiątych XIX wieku towarzyszyło zjawisko szeroko rozumianej rywalizacji. O najbardziej atrakcyjne tereny ubiegali się wtedy nie średnio zamożni obywatele miasta, gdyż ich zasoby były zbyt skromne na podjęcie tego rodzaju przedsięwzięć, lecz przedstawiciele wrocławskiej socjety finansowej i spółki budowlane. Wśród nich prym wiodło Śląskie Towarzystwo Handlu Nieruchomościami. Jego pierwszym spektakularnym sukcesem było nabycie obszaru zwanego Mysim Stawem oraz położonego w centrum miasta terenu po dawnych stajniach miejskich przy ul. Świdnickiej - wykupił je Julius Schottländer jako reprezentujący interesy towarzystwa, które w dniu podpisania umowy (23 marca 1872 r.) pozostawało w organizacji. Niezwykły pośpiech przyszłych udziałowców w finalizowaniu owej transakcji rzuca ciekawe światło na powód zawiązania spółki, świadcząc, że w kręgach wrocławskiej elity finansowej w pełni zadawano sobie sprawę z zyskowności przedsięwzięcia. Powierzenie Juliusowi Schottländerowi prowadzenia negocjacji z przedstawicielami miasta w sprawie zakupu owych terenów stanowi zaś niepodważalny dowód, że już wówczas wysoce ceniono jego handlowy zmysł i darzono wielkim zaufaniem ${ }^{22}$.

22 Bożena Grzegorczyk, „The Operations of Building Companies in Wrocław in the 2nd Half of the 19th Century", Architectus 19, no. 1 (2012): 37. 
Kolejne lata działalności towarzystwa w pełni potwierdziły wyjątkowe zdolności Schottländera w dziedzinie handlu nieruchomościami. Spółka zgromadziła spory areał ziemi w południowej części Wrocławia oraz tereny w okolicach Przedmieścia Szczytnickiego. Julius zaś był od 1866 roku właścicielem majątku rycerskiego Partynice (fot. 1), do którego później przyłączył majątki Kowale, Suchy Dwór, Bledzów, Wysoka, Stary Śleszów oraz Biestrzykowice, a ponadto kupił gospodarstwa chłopskie na Ołtaszynie; w rezultacie został właścicielem dwóch tysięcy hektarów. Rozpoczął wtedy starania - uwieńczone sukcesem - o utworzenie ze swoich posiadłości fideikomisu rodzinnego. Prawdopodobnie była to jedyna w Prusach żydowska ordynacja ziemska ${ }^{23}$.

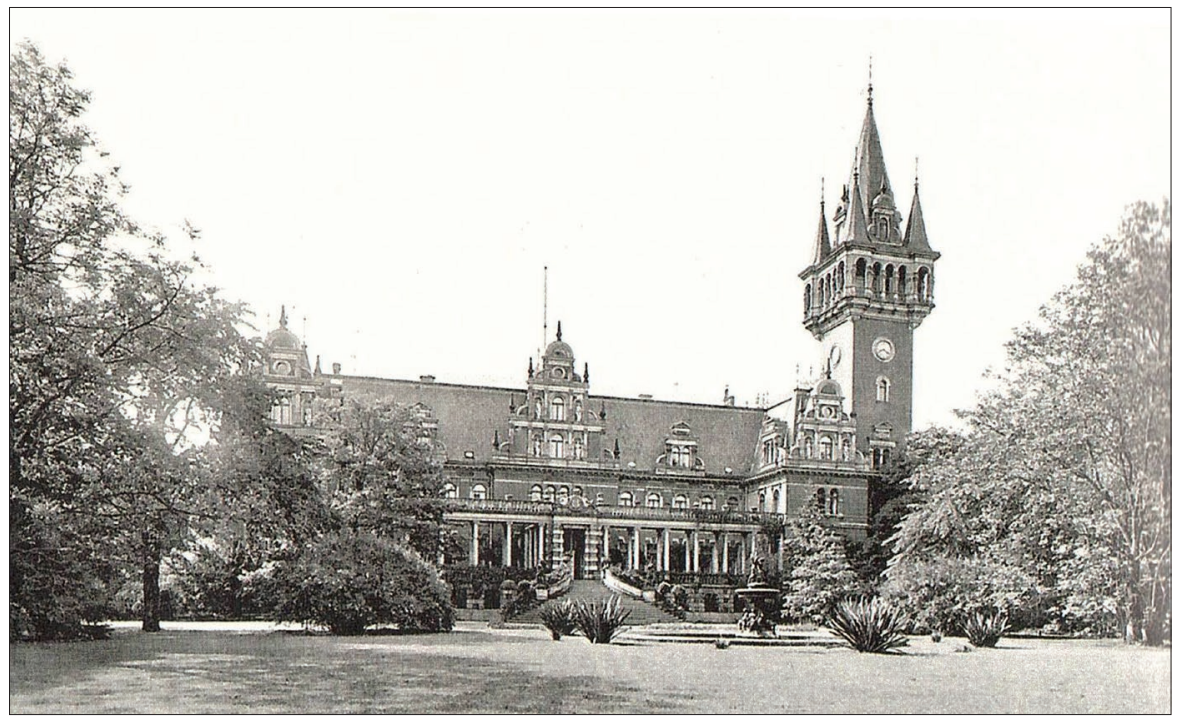

1. Pałac w dawnej wsi Partynice, siedziba Juliusa Schottländera, widok od strony fasady. Fot. ok. 1920, zbiory prywatne.

W tym samym czasie Schottländerowi udało się przejąć od berlińskiego przedsiębiorcy budowlanego Henricha Quistorpa grunty w dawnej wsi Kleinburg24. Quistorp kupił je z zamiarem założenia opodal Wrocławia kolonii

23 Ziątkowski, „Julius Schottländer”, 371.

24 Obecnie to Borek - część Wrocławia, która zajmuje znacznie większy obszar niż kiedyś wieś Kleinburg, dlatego posługuję się niemiecką nazwą, niemającą odpowiednika w języku polskim. 
willowej; już w 1871 roku przystąpił do podziału terenu, lecz prace budowlane posuwały się powoli, a ostatecznie krach giełdowy w Niemczech we wrześniu 1872 roku zmusił go do ogłoszenia upadłości. Choć do tego momentu sprzedano już czterdzieści siedem działek, jedynie na siedemnastu rozpoczęto budowę, w krótkim czasie ukończono roboty na ośmiu z nich. Po upadku przedsiębiorstwa Quistorpa zaprzestano prac budowlanych. Wznowiono je dopiero w 1877 roku, kiedy inwestycję przejął Schottländer. Wrocławski bankier, a zarazem inwestor budowlany o wyjątkowej intuicji w kwestii nieruchomości, jednocześnie mieszkaniec Partynic, które od południa sąsiadowały z Kleinburgiem, zdawał sobie doskonale sprawę z konieczności powiązania odległego osiedla z miastem. Rozmawiał zatem zarządem Wrocławia w sprawie uwzględnienia Kleinburga w tworzonym w 1880 roku projekcie zagospodarowania terenów podmiejskich położonych na południe od Przedmieścia Świdnickiego. Ostatecznie autorzy projektu nowej sieci komunikacyjnej radca budowlany Alexander Kaumann i miejski geometra August Hoffmann - przyjęli jako główną zasadę utrzymanie radialnego układu głównych dojazdów do Wrocławia, z połączeniem ich w odpowiednich miejscach za pomocą ulic wytyczonych w możliwie najbardziej regularny sposób, by zapewnić połączenie z obszarem zabudowanym we wschodniej i zachodniej części miasta. Bez wątpienia ujęcie kolonii willowej w planie zagospodarowania przedmieść dawało szanse na powiązanie jej siecią komunikacyjną z centrum miasta, a w konsekwencji szybszy rozwój ${ }^{25}$.

$\mathrm{O}$ wiele większe znaczenie dla przyspieszenia rozwoju osiedla miała jednak propozycja Juliusa Schottländera przedłożona władzom Wrocławia w latach osiemdziesiątych XIX wieku. Właściciel Partynic zwrócił się wtedy z ofertą przekazania miastu gruntów rozciągających się za południową granicą kolonii w celu urządzenia tam parku. Było to niezwykle trafne posunięcie ze strony Juliusa, gdyż rozwijające się bardzo szybko południowe obrzeża Wrocławia były pozbawione zieleni. Niełatwe negocjacje zarządu Wrocławia z Schottländerem trwały dwa lata - właściciel Kleinburga doskonale zdawał sobie sprawę, że jego dar jest dla miasta nie do przecenienia i stawiał twarde warunki. Później na przeszkodzie do osiągnięcia porozumienia stanęła kwestia zgody Królewskiej Dyrekcji Kolei na poprowadzenie obwodnicy. Pertraktacje w tej sprawie zakończyły się kompromisem dopiero w 1897 roku. Bankier odstąpił grunty konieczne do przeprowadzenia linii towarowej za cenę

25 Tomaszewicz, „Osiedle Borek”, 101-102. 
zaproponowaną przez Dyrekcję Kolei, a miastu przekazał nieodpłatnie około trzydziestu hektarów, z których ponad 25 ha przeznaczono na urządzenie Parku Południowego. Miasto natomiast przystało na żądania bankiera, który za swój „prezent” oczekiwał założenia parku w ciągu pięciu lat i bezterminowego utrzymywania go, przedłużenia jednej z ulic (al. Platanowej) w kierunku południowym aż do granicy dawnego majątku i wyposażenia jej w chodniki, drogę do jazdy konnej i linię tramwajową. Ponadto domagał się wytyczenia dróg przewidzianych w planie zagospodarowania południowej części Przedmieścia Świdnickiego z 1880 roku oraz przyrzeczenia, że na przynależnych do niej terenach zostanie utrzymany zakaz budowy fabryk lub podobnych urządzeń wydzielających dym albo nieprzyjemne zapachy, albo nadmiernie hałasujących. Należy jednak podkreślić, że umowa, jaką władze miasta zawarły z Schottländerem, zawiera również zapis świadczący, że bankier nie kierował się wyłącznie własnym interesem. Zapis ten zobowiązuje odpowiednie władze do pobierania zwiększonych opłat za zużycie gazu i wody przy czym kwoty nadpłacone, podzielone w równych częściach, miały być przekazane wskazanym przez bankiera organizacjom dobroczynnym wspierającym ubogą ludność wyznania katolickiego, ewangelickiego i mojżeszowego. To rozporządzenie wymownie świadczy, że Schottländer interesował się losem niezamożnych mieszkańców, a jego decyzje bywały też podyktowane troską o wspólne dobro.

Wydaje się, że również z myślą o najuboższych Julius nabył w latach siedemdziesiątych spory teren położony między Odrą a ul. Szczytnicką, gdzie w latach czterdziestych XIX wieku był urządzony Ogród Zimowy. Ziemia po dawnym ogrodowym założeniu została pokryta siatką ulic, z których dwie otrzymały nazwy od imion członków jego rodziny: dzisiejsza ul. Wrocławczyka (Paulstr.) i obecna ul. Benedykta Polaka (Gertrudenstr.). Część wytyczonych działek sprzedano, na pozostałych wzniesiono kamienice czynszowe z niewielkimi mieszkaniami, najczęściej dwupokojowymi, ale z instalacją wodno-kanalizacyjną. Trudno powiedzieć, czy budowa kamienic z tanimi mieszkaniami była podyktowana troską o ubogich wrocławian, czy też przedsiębiorca dostrzegł możliwość czerpania zysku z wynajmu lokali mniej zarabiającym. Mieszkania, mimo niewielkiej kubatury, były poprawnie rozplanowane Zaprojektowane zostały wówczas w najbardziej dogodny sposób, a mianowicie w dwutraktowym układzie wnętrz. Całą szerokość frontowego traktu zajmował pokój mieszkalny, przeznaczony dla całej rodziny. W trakcie tylnym ulokowano sypialnię, kuchnię i mały przedpokój. Między kuchnią 
a przedpokojem wygospodarowano miejsce na wc , co świadczyło o nowoczesnym podejściu do spraw higieny przyszłych mieszkańców. Domy utrzymane były w stylistyce późnego historyzmu, o plastycznych fasadach, w dekoracji których zastosowano motywy nawiazujące do architektury renesansu, baroku i klasycyzmu. Aczkolwiek skromne, nie odpowiadały modelowi tzw. czynszowych koszar (Mietskaserne) o jednostajnych fasadach i ciasnych, niefunkcjonalnych pomieszczeniach. Wydaje się, że przedsiębiorca chciał zachować pamięć o wcześniejszym charakterze owego terenu, ponieważ piece kaflowe w mieszkaniach swoją skromną dekoracją - umieszczonymi na płycinach wizerunkami „ogrodników” bądź narzędzi ogrodniczych, kwietnych wiech, owoców - nawiązywały do jego dawnej funkcji ogrodu.

Oprócz omówionych przedsięwzięć, Julius Schottländer przeznaczył pewne fundusze na potrzeby Żydowskiego Zakładu Opieki nad Ludźmi Starymi (Jüdische Altersversorgungs-Anstalt) oraz Domu Pielęgniarek Żydowskich (Jüdischer Schwesterheim). Wiadomo także, że wspierał finansowo założony w 1866 roku Ojczysty Związek Kobiet (Vaterlänische Frauen-Verein) oraz budowę ewangelickiego domu związkowego (Vereinhausu), czyli schroniska dla osób wszystkich konfesji wędrujących w poszukiwaniu pracy zarobkowej. W 1905 roku w dniu swoich siedemdziesiątych urodzin założył wraz z żoną Anną fundację z kapitałem w wysokości trzech milionów marek, której zadaniem miała być dobroczynność oraz działalność na rzecz upiększania Wrocławia i rodzinnych Ziębic.

Julius Schottländer zmarł 1 stycznia 1911 roku. Uroczystości pogrzebowe rozpoczęły się w mieszkaniu zmarłego, przy pokrytym w całości wieńcami i wiązankami kwiatów katafalku, uczestniczyła w nich ogromna liczba żałobników. Obecni byli przedstawiciele władz Wrocławia: nadburmistrz dr Georg Bender, burmistrz Hans Trentin, przewodniczący rady miejskiej, tajny radca sądowy dr Salomon Wilhelm Freud, radca budowlany Alfred von Scholtz, członkowie magistratu i rady miejskiej. Przybyli przedstawiciele Ziębic i Karlovych Varów, w tym członkowie karlovarskiej ochotniczej straży pożarnej, której zmarły był honorowym członkiem. Pojawili się reprezentanci najwyższych władz i duchowieństwa z wielu wiejskich gmin, w których posiadał majątki, a także deputowani z licznych zakładów dobroczynnych i fundacji oraz szpitali różnych konfesji. Powiat wrocławski reprezentował starosta i wielu deputowanych sejmiku powiatowego. Tłumnie przybyli członkowie Towarzystwa Wyścigów Konnych. Zarząd Parków Miejskich reprezentował dyrektor Hugo Richter. Zgromadzeni żałobnicy w uroczystej 


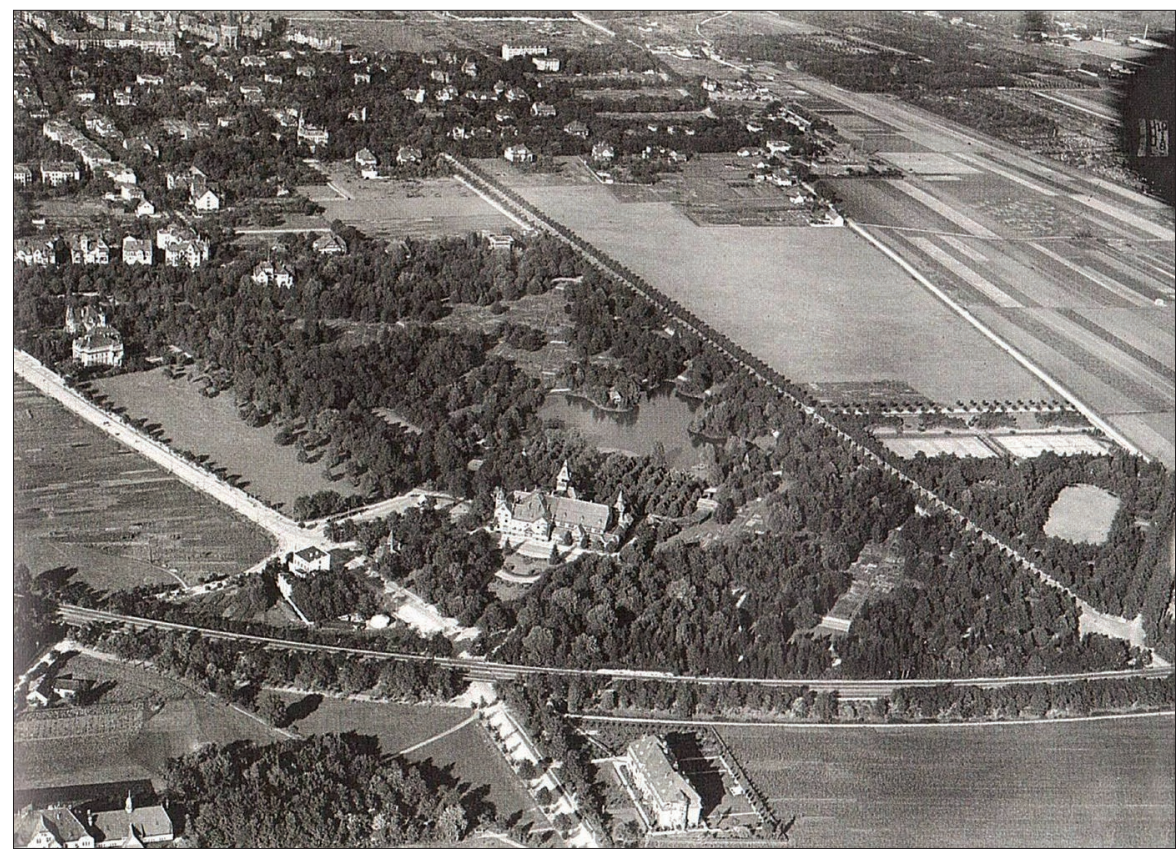

2. Park Południowy, widok od południowego zachodu. Fot. ok. 1930, zbiory prywatne.

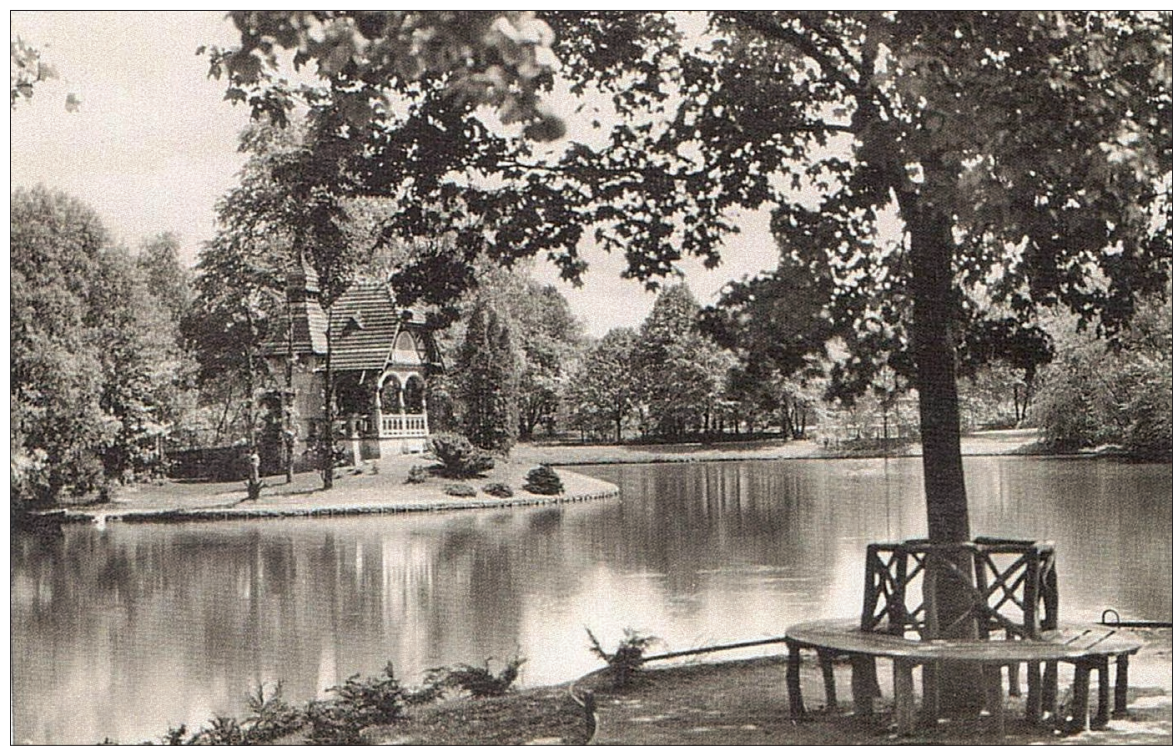

3. Park Południowy, pawilon Juliusa Schottländera. Pocztówka, ok. 1935, zbiory prywatne. 
procesji pogrzebowej odprowadzili zmarłego z centrum miasta na cmentarz przy ul. Ślężnej.

Ów długi kondukt, z udziałem także osób bardziej i mniej oficjalnych, dobitnie potwierdzał, że zmarły cieszył się wśród mieszkańców Wrocławia i okolic ogromnym szacunkiem. Warto przypomnieć, że w tym okresie i szczególnie na terenie Niemiec w społeczności żydowskiej występowało dość specyficzne zjawisko - niektórzy członkowie gmin uwzględniali w życiu zawodowym i prywatnym zarówno elementy żydowskiej tradycji, jak i impulsy z zewnątrz, poddając się świadomie procesowi akulturacji; na ich tożsamość oddziaływały czynniki z obu tych obszarów. Schottländer należał już do tego pokolenia Żydów, które czuło się w środowisku niemieckim dość pewnie, a jego tożsamość była w dużym stopniu zintegrowana z kulturą i społecznością śląską. Ludzie tacy jak on chętnie brali udział w życiu publicznym; często już niezależni od rodzinnych koneksji, nie byli zazwyczaj silnie uwikłani w struktury gminy.

Spośród wielu osób, które w dziewiętnastowiecznym Wrocławiu angażowały się w sprawy miasta, Julius Schottländer niemal podręcznikowo wpisuje się w kategorię patrocinum publicum. Zawarte przezeń z miastem ustalenia dotyczące południowych obszarów Wrocławia miały charakter prawnych umów. Ich realizacja miała w zasadzie charakter ciągły. Bankier, współzałożyciel Śląskiego Towarzystwa Handlu Nieruchomościami i wielokrotny jego rzecznik, później także właściciel kolonii willowej i działek na Przedmieściu Odrzańskim, przyczynił się w dużej mierze do rozwoju miasta nie tylko jako inwestor, dzięki któremu powstało wiele budowli, ale także jako inicjator (i zarazem darczyńca) założenia Parku Południowego (fot. 2, 3). Swój związek z miastem manifestował niemal od początku kariery zawodowej, udzielał się w organizacjach, wielokrotnie finansował społeczne inicjatywy, wspomagał niezamożnych mieszkańców. Angażując się na różnych obszarach funkcjonowania Wrocławia poznawał rozmaite problemy miasta, a jednocześnie zyskiwał wiedzę, którą mógł wykorzystać do rozwiązywania sytuacji konfliktowych i umacniania współpracy mieszkańców. Wrocławianie odwzajemnili się uczestnicząc w jego pogrzebie, publikując na łamach prasy nekrologi i wspomnienia, nazywając jego nazwiskiem jedną z ulic (obecnie ul. Karkonoska). Niewątpliwie Julius Schottländer był czynny w życiu społecznym głównie ze względu na własną pozycję w niemieckiej społeczności, lecz dzięki swemu zaangażowaniu i efektom pracy na rzecz miasta zapisał się na trwałe w historii Wrocławia. 


\section{Bibliografia}

Asch, Ronald G., Brigit Emich, i Jens Ivo Engels. Legitimation. Konsumption. Politische Patronage in Früher Neuzeit und Moderne. Frankfurt am Main: P. Lang, 2011.

Badian, Ernst. Foregin Clientelae, 264-70 B.C. Oxford: Oxford University Press, 1958.

Bińkowska, Iwona. Natura i miasto. Publiczna zieleń miejska we Wrocławiu od schyłku XVIII do początków XX wieku. Wrocław: Muzeum Architektury, 2006.

Briquet, Jean-Louis, i Frédéric Sawicki. Clientélisme politique dans la sociétés contemporaines. Paris: Presses Universitaires de France, 1998.

Gelzer, Mathias. Nobilität der römischen Republik. Stuttgart: Teubner Studentbücher Geschichte, 1983.

Grzegorczyk, Bożena. Pałace-instytucje dziewiętnastowiecznego Wrocławia - znak patronatu obywatelskiego. Toruń: Wydawnictwo Naukowe UMK, 2014.

Grzegorczyk, Bożena. „The Operations of Building Companies in Wrocław in the 2nd Half of the 19th Century”. Architectus 19, no. 1 (2012): 37-46.

Harmand, Louis. Le patronat sur les collectivité publique des orgines au bas empire. Paris: Presses Universitaires de France: 1957.

Heppner, Aron. Jüdische Persönalichkeiten in und das Breslau. Breslau: Th. Schatzky, 1931.

Kolboom, Ingo. „Patron et patronat. Histoire sociale du concept de patronat en France au 19e et 20e siècle”. Mots 9 (1984): 89-112.

Łagiewski, Maciej. Wrocławscy Żydzi 1850-1944. Wrocław: Muzeum Historyczne, 1994.

Marquardt, Joachim. Das Privatlebender Römer. Leipzig: Hirzel, 1886.

Millar, Fergus. The Emperor and the Roman World, 31 B.C.-A.D. 337. Ithaca: Cornell University Press, 1977.

Mommsen,Theodor. „Das römische Gastrecht und die römische Clientele”. Römische Forschungen 1 (1864): 319-390.

Monier, Frédéric, Olivier Dard, i Jens Ivo Engels. Patronage et coruptions politiques dans l'Europe contemporaine. Paris: Armand Colin, 2014.

Moreno-Luzón, Janvier. „Political Clientelism, Elites and Caciquisno in Restoration Spain (1875-1923)”. European History Quarterly 3, no. 37 (2007): 417-441.

Musella, Luigi. "Clientélisme politique et raport entre pouvoir local et système parlamentaire dans la sud d'Italie continentale à la fin de XIX siècle”. Mélange d'école français de Rome 197 (1985): 431-440.

Nicols, John. Civic Patronage in the Roman Empire. Leiden: Koninklije Brill NV, 2014.

Tomaszewicz, Agnieszka. „Osiedle Borek - historia i architektura (1871-1914)”. W Przedmieście Świdnickie we Wrocławiu, red Halina Okólska, 98-110. Wrocław: Wydawnictwo GAJT, 2012.

Ziątkowski, Leszek. „Julius Schottländer (1835-1911). Przykład finansowej i społecznej kariery Żydów wrocławskich”. Sobótka 54 (1999): 365-373. 